\title{
Pengaruh Sanksi Perpajakan Dan Pemahaman Wajib Pajak Terhadap Kepatuhan Wajib Pajak Orang Pribadi Dalam Membayar Pajak Kendaraan Bermotor Di Kota Batam
}

\author{
Dian Efriyenty \\ Dosen Program Studi Akuntansi, Universitas Putera Batam \\ email: dian.efriyenti@puterabatam.ac.id
}

\begin{abstract}
Motor vehicles every year always increase in Batam City. However, the increase in the number of motorized vehicles was not accompanied by an increase in taxpayer compliance. This research was conducted to examine the effect of taxpayer awareness, taxation sanctions and understanding of taxpayers on taxpayer compliance of individuals in paying motor vehicle tax in Batam City. This research was carried out at the SAMSAT Batam Center Riau Islands Office. The number of samples in this study were 100 respondents with the sampling method using the accidental sampling method. The results of the study showed that the taxpayer awareness variable partially did not affect taxpayer compliance. Variable tax sanctions partially have a significant effect on taxpayer compliance. Taxpayer understanding variables partially have a significant effect on taxpayer compliance.
\end{abstract}

Keywords: Tax Sanctions; Understanding Of Taxpayers; Taxpayer Compliance.

\section{PENDAHULUAN}

\section{Latar Belakang}

Kesejahteraan masyarakat dapat diwujudkan dengan menjalankan pemerintahan yang baik dan melaksanakan pembangunan yang merata di setiap daerah. Hal itu tentunya harus didukung oleh sumber dana yang memadai. Salah satu sumber dana pemerintah adalah dari penerimaan pajak. Maka dari itu, penerimaan pajak harus dimaksimalkan agar tercapainya kesejahteraan masyakat secara menyeluruh.

Pajak kendaraan bermotor merupakan salah satu pajak yang memiliki kontribusi yang cukup besar terhadap pendapatan suatu daerah. Kantor SAMSAT Batam Center Kepulauan Riau merupakan salah satu tempat para wajib pajak kendaraan bermotor Kota Batam melakukan pembayaran pajak kendaraan bermotornya, sehingga diharapkan bisa memberikan pelayanan publik yang berkualitas. Besarnya penerimaan Pajak Kendaraan Bermotor (PKB) di Kantor SAMSAT Batam Center Kepulauan Riau dikarenakan peredaran jumlah kendaraan semakin meningkat dari tahun ke tahun. Hal ini bisa dilihat dari tabel 1.1 sebagai berikut:

Tabel 1 Data Jumlah Kendaraan Bermotor dan Penerimaan Pajak Kendaraan Bermotor di Kota Batam

\begin{tabular}{|c|c|c|c|}
\hline No & Tahun & Jumlah Kendaraan & Jumlah Penerimaan Pajak \\
\hline 1 & 2014 & 580.446 & 67.376 .789 .465 \\
\hline 2 & 2015 & 634.744 & 135.987 .260 .896 \\
\hline 3 & 2016 & 704.266 & 146.697 .539 .871 \\
\hline
\end{tabular}

Sumber: Kantor Samsat Batam 
Berdasarkan tabel 1.1 dapat disimpulkan bahwa kepatuhan wajib pajak kendaraan bermotor di Kota Batam masih rendah. Hal ini dapat dlihat dari jumlah kendaraan dan jumlah penerimaan pajak di Kota Batam. Peningkatan jumlah kendaraan di Kota Batam yang cukup signifikan, tidak diiringi dengan jumlah penerimaan pajaknya yang kurang signifikan.

Kepatuhan wajib pajak dapat pula ditingkatkan melalui pengenaan sanksi perpajakan. Undang-undang dan peraturan telah mengatur bagaimana pelaksanaan ketentuan umum dan tata cara perpajakan, termasuk sanksi yang akan dikenakan apabila wajib pajak tidak memenuhi kewajiban perpajakannya. Pelaksanaan dan pemberian sanksi yang dimaksud adalah dalam bentuk pemberian sanksi administrasi atau denda maupun sanksi pidana.

Pemahaman mengenai arti dan manfaat pajak dapat meningkatkan kesadaran dari wajib pajak. Tanpa adanya pengetahuan tentang pajak dan manfaatnya tidak mungkin orang secara ikhlas membayar pajak. Kekhawatiran masyarakat dalam membayar pajak disebabkan maraknya kasus yang sering terjadi khususnya dibidang perpajakan. Kondisi tersebut dapat mempengaruhi kepatuhannya, karena para wajib pajak tidak ingin pajak yang telah dibayarkan disalahgunakan oleh aparat pajak itu sendiri (Arum, 2012).

Kendaraan bermotor tiap tahun selalu meningkat di Kota Batam. Namun, peningkatan jumlah kendaraan bermotor tidak diiringi dengan peningkatan kepatuhan wajib pajak. Hal ini didasarkan pada perbandingan jumlah wajib pajak yang membayar pajak kendaraan bermotor dengan jumlah total wajib pajak efektif. Oleh karena itu, perlu dilakukan penelitian mengenai faktor-faktor yang menyebabkan kepatuhan wajib pajak masih rendah. Variabel yang diduga mempengaruhi kepatuhan wajib pajak dalam penelitian ini adalah sanksi perpajakan dan pemahaman wajib pajak.

Beberapa penelitian tentang kepatuhan wajib pajak telah dilakukan peneliti-peneliti sebelumnya. (Arisandy, 2017) meneliti mengenai Pengaruh pemahaman wajib pajak, kesadaran wajib pajak, dan sanksi pajak terhadap kepatuhan wajib pajak orang pribadi yang melakukan kegiatan bisnis online di Pekanbaru. Oleh karena itu, peneliti termotivasi untuk melakukan penelitian mengenai kepatuhan wajib pajak yang berjudul "Pengaruh Sanksi Perpajakan Dan Pemahaman Wajib Pajak Terhadap Kepatuhan Wajib Pajak Orang Pribadi Dalam Membayar Pajak Kendaraan Bermotor Di Kota Batam".

\section{TINJAUAN PUSTAKA}

\section{Pengertian Pajak}

Pengertian pajak adalah pajak adalah iuran rakyat kepada iuran rakyat kepada kas negara berdasarkan undang-undang (yang dapat dipaksakan) dengan tiada mendapat jasa timbal (kontraprestasi) yang langsung dapat ditunjukkan dan yang digunakan untuk membayar pengeluaran umum (Mardiasmo, 2011).

\section{Pajak Kendaraan Bermotor}

Pajak kendaraan bermotor (PKB) merupakan salah satu penerimaan pajak yang mempengaruhi tingginya pendapatan daerah. Oleh karena itu, perlu adanya optimalisasi dari penerimaan Pajak Kendaraan Bermotor (PKB) melalui berbagai upaya yang mampu meningkatkan jumlah pendapatan dari sektor ini, salah satunya yaitu melalui peningkatan kesadaran wajib pajak dan pengetahuan perpajakan. Namun masih ada upaya yang dapat dilakukan sehingga masyarakat sadar sepenuhnya untuk membayar pajak dan ini bukan sesuatu yang mustahil terjadi. Ketika masyarakat memiliki kesadaran maka membayar pajak akan dilakukan secara sukarela bukan keterpaksaan (Lindawati \& Firdaus Hamta, 2016).

\section{Wajib Pajak Kendaraan Bermotor}

Wajib Pajak Kendaraan Bermotor (PKB) adalah badan atau orang pribadi yang memiliki kendaraan bermotor, apabila wajib pajak berupa badan, maka kewajiban pajaknya diwakili oleh kuasa hukum atau pengurus badan tersebut. Wajib pajak orang pribadi adalah orang pribadi yang menurut ketentuan peraturan perundang-undangan perpajakan ditentukan untuk melakukan kewajiban perpajakan (Mahdi \& Windi Ardiati, 2017).

\section{Kepatuhan Wajib Pajak}


Kepatuhan wajib pajak meliputi yaitu memenuhi kewajiban pajak sesuai dengan ketentuan yang berlaku, membayar pajaknya tepat pada waktunya, wajib pajak memenuhi persyaratan dalam membayar pajaknya, dan wajib pajak mengetahui jatuh tempo pembayaran (Rumiyatun, 2017).

Adapun indikator-indikator yang mempengaruhi kepatuhan wajib pajak dalam penelitian ini antara lain sebagai berikut (Rumiyatun, 2017):

1. Memenuhi kewajiban pajak sesuai dengan ketentuan yang berlaku.

2. Membayar pajaknya tepat pada waktunya.

3. Wajib Pajak memenuhi persyaratan dalam membayarkan pajaknya.

4. Wajib pajak dapat mengetahui jatuh tempo pembayaran.

\section{Sanksi Perpajakan}

Sanksi perpajakan merupakan jaminan bahwa ketentuan peraturan perundang-undangan perpajakan (norma perpajakan) akan dituruti dan atau dipatuhi, dengan kata lain sanksi perpajakan merupakan alat pencegah (preventif) agar wajib pajak tidak melanggar norma perpajakan (Mardiasmo, 2011).

Adapun Indikator sanksi perpajakan dalam penelitian ini antara lain sebagai berikut (Rumiyatun, 2017):

1. Wajib pajak mengetahui mengenai tujuan sanksi pajak kendaraan bermotor.

2. Penggenaan sanksi yang cukup berat merupakan salah satu untuk mendidik wajib pajak.

3. Sanksi Pajak harus dikenakan pada wajib pajak yang melanggar tanpa toleransi.

\section{Pemahaman Wajib Pajak}

Pengetahuan dan pemahaman akan peraturan perpajakan adalah proses dimana wajib pajak mengetahui tentang perpajakan dan mengaplikasikan pengetahuan itu untuk membayar pajak (Nurhakim \& Dudi Pratomo, SET., 2015).

Adapun indikator pemahaman wajib pajak yang digunakan dalam penelitian ini antara lain sebagai berikut (Nurhakim \& Dudi Pratomo, SET., 2015):

1. Pemahaman wajib pajak mengenai kepemilikan STNK.

2. Pengetahuan dan pemahaman mengenai hak dan kewajiban perpajakan.

3. Pengetahuan dan pemahaman atas sanksi perpajakan.

4. Pengetahuan dan pemahaman mengenai tarif pajak.

\section{Penelitian Terdahulu}

Beberapa Penelitian tentang kepatuhan wajib pajak yang telah dilakukan oleh peneliti sebelumnya. (Lindawati \& Firdaus Hamta, 2016) meneliti tentang pengaruh kesadaran wajib pajak dan pengetahuan perpajakan terhadap kepatuhan wajib pajak dalam membayar pajak kendaraan bermotor. Hasil penelitiannya adalah kesadaran wajib pajak dan pengetahuan perpajakan secara serempak berpengaruh secara signifikan terhadap kepatuhan wajib pajak dalam membayar pajak kendaraan bermotor.

(Mahdi \& Windi Ardiati, 2017) meneliti tentang pengaruh kesadaran wajib pajak dan sanksi pajak terhadap kepatuhan wajib pajak orang pribadi pada kantor pelayanan pajak pratama Banda Aceh. Hasil penelitiannya adalah secara simultan kesadaran wajib pajak dan sanksi pajak mempunyai pengaruh positif terhadap kepatuhan wajib pajak pribadi.

\section{METODE}

\section{Desain Penelitian}

Desain penelitian ini menjelaskan metode penelitian yang digunakan menjelaskan metode penelitian yang digunakan dan bagaimana prosedur penelitian tersebut dilakukan. Metode penelitian adalah cara ilmiah untuk mendapatkan data dengan tujuan dan kegunaan tertentu (Sugiyono, 2012). 


\section{Populasi dan Sampel \\ Populasi}

Adapun populasi yang digunakan dalam penelitian ini adalah semua wajib pajak kendaraan bermotor orang pribadi yang ada di Kota Batam tahun 2017. Jumlah populasi penelitian ini adalah 708.321 (sumber data dari SAMSAT Batam) Wajib Pajak Kendaraan Bermotor. Guna efisiensi waktu dan biaya, maka tidak semua wajib pajak kendaraan bermotor tersebut menjadi wajib obyek dalam penelitian ini.

\section{Sampel}

Teknik yang digunakan dalam penentuan sampel ini adalah teknik accidental sampling yang merupakan bagian dari Non Probability Sampling. Penentuan sampel disini ditentukan dengan menggunakan pendekatan slovin.

Berdasarkan data dari Kantor Samsat Batam Center Kepulauan Riau, tercatat sabanyak 708.321 wajib pajak kendaraan bermotor orang pribadi, sehingga jumlah sampel didalam penelitian ini 100 responden.

\section{Variabel Dan Indikator}

Dalam penelitian ini terdiri dari variabel dependen dan independen. Variabel dependen yang digunakan adalah kepatuhan wajib pajak, sedangkan variabel independen yang digunakan adalah sanksi perpajakan dan pemahaman wajib pajak

\section{Variabel Dependen} pajak.

Dalam penelitian ini, penelitian dependen yang digunakan adalah kepatuhan wajib

Tabel 2 Variabel Dependen dan Indikatornya

\begin{tabular}{|c|c|c|}
\hline Variabel & Indikator & Skala \\
\hline Kepatuhan Wajib Pajak & $\begin{array}{l}\text { 1. Memenuhi kewajiban pajak sesuai } \\
\text { dengan ketentuan yang berlaku. } \\
\text { 2. Membayar pajaknya tepat pada } \\
\text { waktunya. } \\
\text { 3. Wajib Pajak memenuhi persyaratan } \\
\text { dalam membayarkan pajaknya. } \\
\text { 4. Wajib pajak dapat mengetahui } \\
\text { jatuh tempo pembayaran. }\end{array}$ & Skala Likert \\
\hline
\end{tabular}

Sumber Indikator Tingkat Kepatuhan: (Rumiyatun, 2017)

\section{Variabel Independen}

Dalam penelitian ini, variabel independen yang digunakan ada tiga variabel yaitu kesadaran wajib pajak, sanksi perpajakan dan pemahaman wajib pajak.

Tabel 3 Variabel Indipenden dan Indikatornya

\begin{tabular}{|c|c|c|}
\hline Variabel & Indikator & Skala \\
\hline $\begin{array}{l}\text { Sanksi } \\
\text { Perpajakan }\end{array}$ & $\begin{array}{l}\text { 1. Wajib pajak mengetahui mengenai tujuan sanksi } \\
\text { pajak kendaraan bermotor. } \\
\text { 2. Penggenaan sanksi yang cukup berat merupakan } \\
\text { salah satu untuk mendidik wajib pajak. } \\
\text { 3. Sanksi Pajak harus dikenakan pada wajib pajak } \\
\text { yang melanggar tanpa toleransi. }\end{array}$ & $\begin{array}{l}\text { Skala } \\
\text { Likert }\end{array}$ \\
\hline $\begin{array}{l}\text { Pemahaman } \\
\text { Wajib Pajak }\end{array}$ & $\begin{array}{l}\text { 1. Pemahaman wajib pajak mengenai kepemilikan } \\
\text { STNK. } \\
\text { 2. Pengetahuan dan pemahaman mengenai hak dan } \\
\text { kewajiban perpajakan. } \\
\text { 3. Pengetahuan dan pemahaman atas sanksi }\end{array}$ & $\begin{array}{l}\text { Skala } \\
\text { Likert }\end{array}$ \\
\hline
\end{tabular}




\begin{tabular}{|l|l|l|}
\hline & $\begin{array}{l}\text { perpajakan. } \\
\text { Pengetahuan dan pemahaman mengenai tarif } \\
\text { pajak. }\end{array}$ & \\
\hline
\end{tabular}

Sumber Indikator Sanksi Perpajakan: (Rumiyatun, 2017)

Sumber Indikator Pemahaman Wajib Pajak: (Nurhakim \& Dudi Pratomo, SET., 2015)

\section{Teknik Pengumpulan Data}

Teknik pengumpulan data dalam penelitian ini meliputi data primer dalam penelitian ini diperoleh dari kuesioner yang diisi oleh wajib pajak sedangkan data sekunder merupakan data yang diperoleh atau dikumpulkan peneliti dari berbagai sumber yang telah ada (peneliti sebagai tangan kedua). Data sekunder dalam penelitian ini dapat diperoleh dari berbagai sumber dan instansi-instansi yang terkait dengan penelitian, buku, laporan, jurnal dan lain sebagainya.

\section{Metode Analisis Data}

Metode analisa didalam penelitian ini menggunakan analisis regresi linear berganda dengan pengujian hipotesis.

\section{HASIL DAN PEMBAHASAN \\ Deskripsi Objek Penelitian \\ Gambaran Umum Objek Penelitian}

Kantor SAMSAT Batam Center Kepulauan Riau merupakan salah satu tempat pelayanan masyarakat yang berhubungan dengan segala jenis pajak kendaraan bermotor di Kota Batam. Penelitian ini mengambil sampel wajib pajak yang peneliti temui sedang membayar pajak kendaraan bermotor di Kantor SAMSAT Batam Center Kepulauan Riau sebanyak 100 responden.

\section{Hasil Uji Statistik Deskriptif}

Statistik deskriptif adalah statistik yang berkenan dengan bagaimana cara mendeskriptifkan, menggambarkan, menjabarkan, atau menguraikan data agar mudah dipahami. Hasil dari analisis deskriptif dapat diihat dalam tabel 4 berikut.

Tabel 4 Statistik Deskriptif

Descriptive Statistics

\begin{tabular}{|l|r|r|r|r|r|}
\hline & \multicolumn{1}{|c|}{ N } & Minimum & Maximum & Mean & Std. Deviation \\
\hline X1 & 100 & 13,00 & 18,00 & 15,4900 & 1,16771 \\
X2 & 100 & 13,00 & 20,00 & 15,6700 & 1,45682 \\
X3 & 100 & 12,00 & 20,00 & 16,3400 & 1,81587 \\
Y & 100 & 14,00 & 20,00 & 15,7300 & 1,46925 \\
Valid N & 100 & & & & \\
(listwise) & & & & & \\
\hline
\end{tabular}

Sumber : Lampiran Output SPSS

Dari tabel diatas dapat kita lihat bahwa data yang digunakan adalah valid. Kolom $\mathrm{N}$ menunjukan jumlah data yang diproses. Kolom minimum menunjukan nilai paling kecil dari data untuk variabel X1 nilai minimum yatu 13,00 untuk variabel $\mathrm{X} 2$ nilai minimum yaitu 13,00 untuk variabel X3 nilai minimum yaitu 12,00 dan untuk variabel Y nilai minimum yaitu 14,00. Sedangkan untuk kolom maksimum menunjukan nilai terbesar dari variabel X1 yaitu 18,00, untuk variabel $\mathrm{X} 2$ nilai maksimum yaitu 20,00 untuk variabel $\mathrm{X} 3$ nilai maksimum yaitu 20,00 dan untuk variabel Y nilai maksimum 20,00. Mean menunjukan nilai mean dari data setiap variabel, sedangkan kolom Std. Deviation menunjukan nilai standar deviasi data. 


\section{Uji Pengaruh}

Hasil Uji t

Tujuan dilakukan uji signifikasi secara parsial tiga variabel bebas terhadap variabel tak bebas adalah untuk mengukur secara terpisah dampak yang ditimbulkan dari masing-masing variabel bebas terhadap variabel tak bebas.

Hasil uji t (parsial) dalam penelitian ini, dapat dilihat pada tabel 5 sebagai berikut:

Tabel 5 Uji t

Coefficients $^{\mathrm{a}}$

\begin{tabular}{|c|c|c|c|c|c|c|}
\hline \multirow{2}{*}{\multicolumn{2}{|c|}{ Model }} & \multicolumn{2}{|c|}{ Unstandardized Coefficients } & \multirow{2}{*}{$\begin{array}{c}\begin{array}{c}\text { Standardized } \\
\text { Coefficients }\end{array} \\
\text { Beta }\end{array}$} & \multirow[b]{2}{*}{$\mathrm{t}$} & \multirow[b]{2}{*}{ Sig. } \\
\hline & & $\mathrm{B}$ & Std. Error & & & \\
\hline 1 & (Constant) & 7,882 & 2,170 & & 3,633 &, 000 \\
\hline & $\mathrm{X} 1$ & ,272 & ,099 & ,270 & 2,755 &, 007 \\
\hline & $\mathrm{X} 2$ & ,264 & ,075 & ,326 & 3,499 & 001 \\
\hline
\end{tabular}

a. Dependent Variable: Y

Sumber: Lampiran output SPSS

Dari tabel diatas dapat dilihat bahwa variabel Sanksi perpajakan memiliki nilai t hitung sebesar 2,755 lebih besar dari nilai t tabel sebesar 1,660 dengan nilai signifikansi 0,007 nilai ini lebih kecil dari 0,05. Sehingga dapat disimpulkan bahwa Ho ditolak dan Ha diterima, yang berarti bahwa Sanksi perpajakan berpengaruh terhadap kepatuhan wajib pajak orang pribadi dalam membayar pajak kendaraan bermotor di Kota Batam, maka H1 dan H2 diterima.

Dari tabel diatas dapat dilihat bahwa variabel Pemahaman wajib pajak memiliki nilai $t$ hitung sebesar 3,499 lebih besar dari nilai t tabel sebesar 1,660 dengan nilai signifikansi 0,001 nilai ini lebih kecil dari 0,05. Sehingga dapat disimpulkan bahwa Ho ditolak dan Ha diterima, yang berarti bahwa Pemahaman wajib pajak berpengaruh terhadap Kepatuhan Wajib pajak orang pribadi dalam membayar pajak kendaraan bermotor di Kota Batam, maka $\mathrm{H} 2$ diterima.

\section{Hasil Uji F}

Pengujian ini dilakukan untuk mengetahui apakah variabel bebas yang dimaksudkan dalam model memiliki pengaruh secara bersama-sama terhadap variabel terikat. Hasil uji $\mathrm{F}$ (simultan) dapat dilihat pada tabel 6 sebagai berikut:

Tabel 6 Hasil Uji F

ANOVA $^{\mathrm{a}}$

\begin{tabular}{|ll|r|r|r|r|r|}
\hline \multicolumn{2}{|l|}{ Model } & \multicolumn{1}{|c|}{$\begin{array}{c}\text { Sum of } \\
\text { Squares }\end{array}$} & df & Mean Square & F & Sig. \\
\hline 1 & Regression & 45,690 & 3 & 15,230 & 8,702 &, $000^{\mathrm{b}}$ \\
& Residual & 168,020 & 96 & 1,750 & & \\
& Total & 213,710 & 99 & & & \\
\hline
\end{tabular}

a. Dependent Variable: Y

b. Predictors: (Constant), X3, X1, X2

Sumber: Lampiran output SPSS

Dari tabel diatas dapat dilihat bahwa variabel Sanksi perpajakan, dan Pemahaman wajib memiliki nilai signifikansi 0,00 nilai ini lebih kecil dari 0,05 dan nilai $\mathrm{F}$ hitung sebesar 8,702 lebih besar dari nilai $\mathrm{F}$ tabel sebesar 2,699 sehingga dapat disimpulkan bahwa Sanksi perpajakan, dan Pemahaman wajib pajak secara simultan berpengaruh terhadap Kepatuhan Wajib pajak orang pribadi dalam membayar pajak kendaraan bermotor di Kota Batam. 


\section{Pembahasan}

Berdasarkan hasil pengujian secara statistik dapat terlihat bahwa secara simultan variabel bebas berpengaruh terhadap variabel terikat.

\section{Pengaruh Sanksi Perpajakan Terhadap Kepatuhan Wajib Pajak}

Hasil pengujian hipotesis telah membuktikan terdapat pengaruh sanksi perpajakan terhadap kepatuhan wajib pajak. Melalui hasil perhitungan yang telah dilakukan, diperoleh nilai t hitung sebesar 2,755 lebih besar dari nilai t tabel sebesar 1,660 dengan tarif signifikansi hasil sebesar 0,007 lebih kecil dari 0,05 maka Ha diterima dan Ho ditolak. Pengujian ini secara statistik membuktikan sanksi perpajakan berpengaruh positif terhadap kepatuhan wajib pajak. Artinya, bahwa ada pengaruh variabel sanksi perpajakan terhadap kepatuhan wajib pajak orang pribadi dalam membayar pajak kendaraan bermotor di Kota Batam. Hasil ini mendukung penelitian sebelumnya oleh (Arisandy, 2017) yang menguji pengaruh pemahaman wajib pajak, kesadaran wajib pajak dan sanksi pajak terhadap kepatuhan wajib pajak orang pribadi yang melakukan kegiatan bisnis online di Pekanbaru dengan hasil analisis yaitu sanksi pajak berpengaruh signifikan terhadap kepatuhan wajib pajak orang pribadi.

\section{Pengaruh Pemahaman Wajib Pajak Terhadap Kepatuhan Wajib Pajak}

Hasil pengujian hipotesis telah membuktikan terdapat pengaruh pemahaman wajib pajak terhadap kepatuhan wajib pajak. Melalui hasil perhitungan yang telah dilakukan, diperoleh nilai $t$ hitung sebesar 3,499 lebih besar dari nilai t tabel sebesar 1,660 dengan tarif signifikansi sebesar 0,001 lebih kecil dari 0,05 maka Ha diterima dan Ho ditolak. Pengujian ini secara statistik membuktikan pemahaman wajib pajak berpengaruh positif terhadap kepatuhan wajib pajak. Artinya, bahwa ada pengaruh variabel pemahaman wajib pajak terhadap kepatuhan wajib pajak orang pribadi dalam membayar pajak kendaraan bermotor di Kota Batam. Hasil ini mendukung penelitian sebelumnya oleh (Nurhakim \& Dudi Pratomo, SET., 2015) yang menguji pengaruh pemahaman wajib pajak dan kualitas pelayanan terhadap kepatuhan wajib pajak dengan hasil analisis yaitu pemahaman wajib pajak berpengaruh signifikan terhadap kepatuhan wajib pajak.

\section{Pengaruh Sanksi Perpajakan dan Pemahaman Wajib Pajak Terhadap Kepatuhan Wajib Pajak}

Hasil pengujian hipotesis telah membuktikan terdapat pengaruh Sanksi Perpajakan dan Pemahaman Wajib Pajak terhadap Kepatuhan Wajib Pajak. Melalui hasil perhitungan yang telah dilakukan, diperoleh nilai $\mathrm{F}$ hitung sebesar 8,702 lebih besar dari nilai $\mathrm{F}$ tabel sebesar 2,699 dengan nilai signifikansi sebesar 0,000 nilai ini lebih kecil dari 0,05 sehingga dapat disimpulkan bahwa Sanksi perpajakan, dan Pemahaman wajib pajak secara simultan berpengaruh terhadap Kepatuhan Wajib pajak orang pribadi dalam membayar pajak kendaraan bermotor di Kota Batam Ho ditolak dan Ha diterima. Hasil ini mendukung penelitian sebelumnya oleh (Rumiyatun, 2017) yang menguji pengaruh pengetahuan wajib pajak, kesadaran wajib pajak, sanksi pajak kendaraan bermotor dan sistem samsat drive thru terhadap kepatuhan wajib pajak kendaraan bermotor.

\section{SIMPULAN}

Dari pembahasan yang telah diuraikan, maka dapat ditarik kesimpulan sebagai berikut:

1. Hasil pengujian hipotesis telah membuktikan terdapat pengaruh sanksi perpajakan terhadap kepatuhan wajib pajak. Melalui hasil perhitungan yang telah dilakukan, diperoleh nilai t hitung sebesar 2,755 lebih besar dari nilai t tabel sebesar 1,660 dengan tarif signifikansi hasil sebesar 0,007 lebih kecil dari 0,05 sehingga sanksi perpajakan berpengaruh signifikan terhadap kepatuhan wajib pajak

2. Hasil pengujian hipotesis telah membuktikan terdapat pengaruh pemahaman wajib pajak terhadap kepatuhan wajib pajak. Melalui hasil perhitungan yang telah dilakukan, 
diperoleh nilai t hitung sebesar 3,499 lebih besar dari nilai t tabel sebesar 1,660 dengan tarif signifikansi sebesar 0,001 lebih kecil dari 0,05 sehingga pemahaman wajib pajak berpengaruh signifikan terhadap kepatuhan wajib pajak.

3. Berdasarkan perhitungan menggunakan uji $\mathrm{f}$ diperoleh bahwa variabel Sanksi perpajakan, dan Pemahaman wajib memiliki nilai $\mathrm{F}$ hitung sebesar 8,702 lebih besar dari nilai $\mathrm{F}$ tabel sebesar 2,699 dengan nilai signifikansi 0,000 lebih kecil dari 0,05 sehingga dapat disimpulkan bahwa Sanksi perpajakan, dan Pemahaman wajib pajak secara simultan berpengaruh terhadap Kepatuhan Wajib pajak orang pribadi dalam membayar pajak kendaraan bermotor di Kota Batam.

\section{SARAN}

\section{Aspek Teoritis}

Berdasarkan hasil penelitian, penulis mencoba memberikan saran teoritis bagi para akademisi dan peneliti selanjutnya adalah sebagai berikut:

1. Bagi Akademisi

Penelitian ini diharapkan mampu menambah pengetahuan dan wawasan mengenai sanksi perpajakan dan pemahaman wajib pajak khususnya dalam hal mematuhi kepatuhan wajib pajak orang pribadi.

2. Bagi Penelitian Selanjutnya

Penelitian ini diharapkan dapat menjadi masukan referensi bagi peneliti selanjutnya yang melakukan penelitian tentang faktor-faktor yang mempengaruhi kepatuhan wajib pajak orang pribadi.

\section{Aspek Praktis}

Berdasarkan hasil penelitian, penulis mencoba memberikan saran sebagai berikut:

1. Bagi Kantor SAMSAT

Bagi petugas pajak di Kantor SAMSAT Batam Center Kepulauan Riau diharapkan dapat mempertahankan dan meningkatkan kualitas pelayanan yang sudah baik agar wajib pajak tetap merasa puas dan agar tercipta tercipta keinginan, kesadaran dan pemahaman wajib pajak dalam membayar pajak kendaraan bermotor di Kantor SAMSAT Batam Center Kepulauan Riau.

2. Bagi Wajib Pajak

Wajib pajak khususnya wajib pajak orang pribadi untuk meningkatkan kesadarannya dan pemahamannya dalam membayar pajak. Karena jika wajib pajak tidak sadar dan tidak paham, kepatuhan wajib pajak tidak akan terlaksanakan. Maka disarankan sebaiknya wajib pajak memperluas pengetahuannya tentang peraturan perpajakan agar dapat lebih patuh dalam memenuhi kewajibannya. Karena jika tidak, ada sanksi yang akan diberikan kepada wajib pajak yang melanggar.

\section{DAFTAR PUSTAKA}

Andreas, \& Savitri, E. (2015). The Effect of Tax Socialization, Tax Knowledge, Expediency of Tax ID Number and Service Quality on Taxpayers Compliance With Taxpayers Awareness as Mediating Variables, 211(September), 163-169. https://doi.org/10.1016/j.sbspro.2015.11.024

Arisandy, N. (2017). Pengaruh Pemahaman Wajib Pajak, Kesadaran Wajib Pajak Dan Sanksi Pajak Terhadap Kepatuhan Wajib Pajak Orang Pribadi Yang Melakukan Kegiatan Bisnis Online Di Pekanbaru Nelsi, 14(1), 62-71.

Arum. (2012). Pengaruh Kesadaran Wajib Pajak, Pelayanan Fiskus, dan Sanksi Pajak Terhadap Kepatuhan Wajib Pajak Orang Pribadi Yang Melakukan Kegiatan Usaha dan Pekerjaan Bebas (Studi di Wilayah KPP Pratama Cilacap).

Lindawati, \& Firdaus Hamta. (2016). Pengaruh Kesadaran Wajib Pajak Dan Pengetahuan Perpajakan Terhadap Kepatuhan Wajib Pajak Dalam Membayar Pajak Kendaraan Bermotor (Studi Kasus SAMSAT Batam), 3(1), 1-18. 
Mahdi, \& Windi Ardiati. (2017). Pengaruh Kesadaran Wajib Pajak Dan Sanksi Pajak Terhadap Kepatuhan Wajib Pajak Orang Pribadi Pada Kantor Pelayanan Pajak Pratama Banda Aceh, $3(1), 22-31$.

Mardiasmo. (2011). Perpajakan : Edisi Revisi (2013th ed.). Yogyakarta: Andi.

Nurhakim, T., \& Dudi Pratomo, SET., M. A. (2015). Pengaruh Pemahaman Wajib Pajak Dan Kualitas Pelayanan Terhadap Kepatuhan Wajib Pajak Badan (Studi Pada Kantor Pelayanan Pajak Pratama Tasikmalaya). E-Proceeding of Managemen, 2(3), 3426-3433.

Priyatno, D. (2012). BELAJAR ALAT ANALISIS DATA DAN CARA PENGOLAHANNYA DENGAN SPSS. Yogyakarta: ANDI.

Pujiwidodo, D. (2016). Persepsi Sanksi Perpajakan Terhadap Kepatuhan Wajib Pajak Orang Pribadi. Jurnal Online Insan Akuntan, 1(1), 92-116.

Rahayu, N. (2017). Pengaruh Pengetahuan Perpajakan , Ketegasan Sanksi Pajak , Dan Tax Amnesty Terhadap Kepatuhan Wajib Pajak, 1(1), 15-30.

Rumiyatun, D. K. W. (2017). Pengaruh Pengetahuan Wajib Pajak, Kesadaran Wajib Pajak, Sanksi Pajak Kendaraan Bermotor, Dan Sistem Samsat Drive Thru Terhadap Kepatuhan Wajib Pajak Kendaraan Bermotor ( Studi kasus WP PKB roda empat di Samsat Drive Thru Bantul ), 5(1). https://doi.org/10.24964/ja.v5i1.253

Savitri, E., \& Musfialdy. (2016). The Effect of Taxpayer Awareness, Tax Socialization, Tax Penalties, Compliance Cost at Taxpayer Compliance With Service Quality as Mediating Variable, 219, 682-687. https://doi.org/10.1016/j.sbspro.2016.05.051

Sugiyono. (2012). Metode Penelitian Kuantitatif Kualitatif Dan R\&D. Bandung: Alfabeta.

Susilawati, K. E., \& Budiartha, K. (2013). Pengaruh kesadaran wajib pajak, pengetahuan pajak, sanksi perpajakan dan akuntabilitas pelayanan publik pada kepatuhan wajib pajak kendaraan bermotor, 2, 345-357. 